\title{
Note
}

\section{Effects of Pre-heating on Freeze-thaw Fractionation of Soymilk}

\author{
Kazuhiro Morita $^{1^{*}}$, Makoto Shimoyamada ${ }^{2}$ and Mitsutoshi NAKAJIMA ${ }^{3}$ \\ ${ }^{I}$ Food Research Institute, Toyama Prefectural Agricultural, Forestry and Fisheries Research Center, Yoshioka 360, Toyama \\ 939-8153, Japan \\ ${ }^{2}$ School of Food and Nutritional Sciences, University of Shizuoka, Yada 52-1 Suruga-ku, Shizuoka 422-8526, Japan \\ ${ }^{3}$ Faculty of Life and Environmental Sciences, University of Tsukuba, 1-1-1 Tennodai, Tsukuba, Ibaraki 305-8572, Japan
}

Received March 3, 2017 ; Accepted May 25, 2017

Raw soymilk separates into two layers (upper and lower) upon freeze-thawing. In this study, we investigated the effects of heating $\left(50-95^{\circ} \mathrm{C}\right)$ before freezing on the freeze-thaw fractionation of soymilk. Proportion of the upper layer decreased as the heating temperature before freezing was elevated, and heating at $80^{\circ} \mathrm{C}$ completely inhibited the fractionation. The amount of protein in the upper layer decreased with higher heating temperatures, and the $7 \mathrm{~S}$ globulin contents in the lower layer increased simultaneously. The particle size of the upper layer decreased with increased heating temperatures, whereas the particle size of the lower layer increased at temperatures greater than about $70^{\circ} \mathrm{C}$. These results suggested that the changes in soymilk fractionation are likely due to the liberation of $7 \mathrm{~S}$ globulin from lipid/protein complexes upon heating, and interactions among the proteins and lipid/protein complexes caused by freeze-mediated concentration.

Keywords: freeze-thaw, heating temperature, soymilk

\section{Introduction}

Soymilk is a nutritious, plant-based drink that is consumed worldwide, and is an important source of tofu curds (soybean curds). Not only is soymilk processed into a beverage and tofu curds, but it is also utilized as a substitute for milk to produce desserts, such as pudding-like dishes, ice cream, and sweet biscuits; thus, the applications of soymilk are increasing.

To further expand the potential uses of soymilk, a new texture of soymilk has been developed using a freeze-thaw process. The heated soy protein dispersion or soymilk is coagulated by a freezethaw process, and the coagulated material has a soft texture that is different from that of tofu curds (Hashizume, 1971; Shimoyamada et al., 1999). Hashizume (1979) suggested that this coagulated material might be utilized as an additive for hams, sausages, and similar products. Notably, raw soymilk can be separated into two layers (upper and lower) by a freeze-thaw process, and both layers have different physicochemical properties such as protein content, lipid content, and ratio of 7S and 11S globulins (Morita and Yokoi, 2011). Tofu curds made from the $7 \mathrm{~S}$ globulin-rich fraction (upper layer) are soft and smooth, whereas those made from the $11 \mathrm{~S}$ globulin-rich fraction (lower layer) are firm. We previously reported a novel dessert-like product made from the upper layer of freeze-thawed soymilk (Morita, 2013). Sensory evaluations showed that the product made from only the upper layer was tastier than that made from whole soymilk. By utilizing processed soymilk, it may be possible to produce foods with novel textures.

To date, only raw or unheated soymilk has been subjected to freeze-thaw fractionation and the effects of temperature of preheating on the properties of soymilk have not been reported. In this study, we investigated the effects of heating before freezing on soymilk fractionation by freeze-thawing, as well as the properties of the resulting soymilk. 


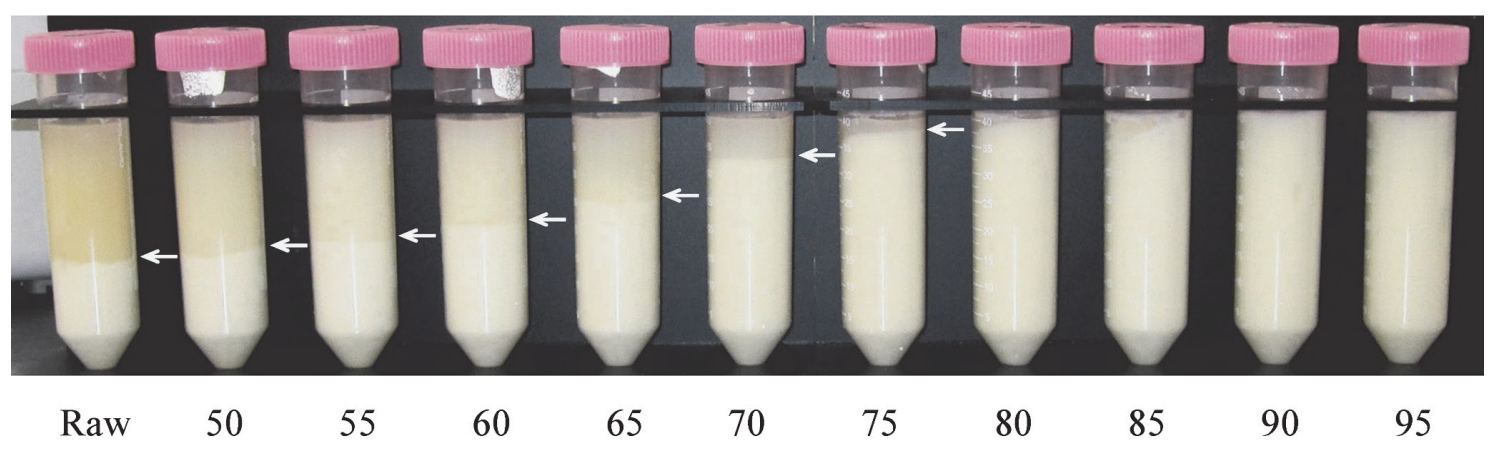

\section{Heating temperature $\left({ }^{\circ} \mathrm{C}\right)$}

Fig. 1. Effect of heating temperature on the freeze-thaw fractionation of soymilk. Arrows indicate the boundary between the upper and lower layers in each sample.

\section{Materials and Methods}

Preparation of soymilk Soymilk was manually prepared from commercially available soybeans (Glycine $\max (\mathrm{L}$.) Merrill, Enrei). Specifically, soymilk samples were prepared by the nama-shibori method with some modifications (Toda et al., 2007). Soybeans were washed and soaked in distilled water at $20^{\circ} \mathrm{C}$ for $16 \mathrm{~h}$. The swollen soybeans were then drained and ground into a homogenate with a volume of distilled water equivalent to six times the dry weight of the soybeans. The homogenate was filtered through an absorbent cotton sheet to remove the okara. This filtrate was termed raw soymilk. The resulting raw soymilk contains $70 \mathrm{~g} \mathrm{~kg}^{-1}$ protein and $36 \mathrm{~g} \mathrm{~kg}^{-1}$ lipid. The raw soymilk was divided into $100 \mathrm{~mL}$ portions, and heated in an oil bath adjusted at 50, 55, 60, 65, 70, $75,80,85,90$, or $95^{\circ} \mathrm{C}$. After reaching the designated temperature, the sample was maintained for 2 min and then cooled rapidly in ice-cold water to $20^{\circ} \mathrm{C}$. Immediately after cooling, these soymilk samples were frozen in a freezer.

Freeze-thaw treatment of soymilk The raw and heated soymilk samples were aliquoted into individual plastic tubes $(40 \mathrm{~mL}$ each). The soymilk samples were frozen at $-30^{\circ} \mathrm{C}$ for $7 \mathrm{~d}$, and then thawed at $10^{\circ} \mathrm{C}$ for $24 \mathrm{~h}$, as reported previously (Morita and Shimoyamada, 2013).

Evaluation of the physicochemical properties of soymilk After freeze-thawing, the soymilk samples separated into two layers; the supernatant (upper) layer was carefully collected by decantation so as to not include the precipitate (lower) layer, and the wet weight of the upper layer was determined. The weight ratios of the upper and lower layers to the total weight were obtained. The protein contents of the soymilk samples were determined by the Kjeldahl method (Kjeldahl, 1883) using a Super Kjel 1500 (Actac Co., Tokyo, Japan), with a nitrogen-to-protein conversion factor of 6.25. The lipid contents of the soymilk samples were determined by chloroform-methanol extraction (Bligh and Dyer, 1959).

SDS-PAGE of soymilk proteins Soymilk proteins were separated by sodium dodecyl sulfate-polyacrylamide gel electrophoresis (SDS-PAGE) (Laemmli, 1970) and stained with Coomassie brilliant blue R-250.
Particle size distribution The particle size distribution of the soymilk was analyzed with a laser diffraction particle size analyzer (SALD-2100; Shimadzu Co., Kyoto, Japan).

\section{Results and Discussion}

Effects of heating temperature before freezing on the freezethaw fractionation of soymilk First, we evaluated the effects of heating before freezing on the freeze-thaw fractionation of soymilk. The raw soymilk samples were heated at $50-95^{\circ} \mathrm{C}$, and then frozen at $-30^{\circ} \mathrm{C}$. After $7 \mathrm{~d}$, the frozen samples were thawed at $10^{\circ} \mathrm{C}$ for $24 \mathrm{~h}$. After freeze-thawing, the raw soymilk prepared without heating separated into two layers (upper and lower), while the heated soymilk $\left(95^{\circ} \mathrm{C}\right)$ coagulated (Fig. 1). The volume of the upper layer decreased as the heating temperature increased, and heating at $80^{\circ} \mathrm{C}$ completely inhibited the fractionation of soymilk.

To evaluate the effects of heating temperature on soymilk fractionation, the weight ratios, protein and lipid contents in each layer were determined (Table 1). The weight ratio of the upper layer to the lower layer decreased as the heating temperature increased. On the other hand, the protein contents in the upper layer were similar at all heating temperatures, whereas the protein contents in the lower layer decreased as the heating temperature increased. Thus, the amount of protein in the upper layer to lower layer decreased as the heating temperature increased. Therefore, heating before freezing likely facilitated the transfer of proteins from the upper layer of raw soymilk to the lower layer. The lipid contents in the upper layer were almost equivalent between 50 and $60^{\circ} \mathrm{C}$, and then decreased, whereas the lipid contents in the lower layer consistently decreased as the heating temperature increased. Therefore, the amount of lipid in the upper layer to lower layer decreased as the heating temperature increased. However, most of the lipids were contained in the lower layer at all tested heating temperatures.

Protein composition of soymilk after freeze-thawing To determine the effects of heating temperature on the protein compositions of the upper and lower layers of soymilk, the proteins were analyzed by SDS-PAGE. In the SDS-PAGE patterns of the 
Table 1. Effects of heating temperature on the weight ratios, protein and lipid contents of the upper and lower layers of soymilk following freeze-thaw fractionation.

\begin{tabular}{|c|c|c|c|c|c|c|c|c|c|c|}
\hline \multirow{3}{*}{$\begin{array}{c}\text { Heating } \\
\text { temperature } \\
\left({ }^{\circ} \mathrm{C}\right)\end{array}$} & \multirow{2}{*}{\multicolumn{2}{|c|}{ Weight ratio (\%) }} & \multicolumn{4}{|c|}{ Protein } & \multicolumn{4}{|c|}{ Lipid } \\
\hline & & & \multicolumn{2}{|c|}{ Content (\%) } & \multicolumn{2}{|c|}{ Amount $\left(\mathrm{g} \mathrm{kg}^{-1}\right)$} & \multicolumn{2}{|c|}{ Content (\%) } & \multicolumn{2}{|c|}{ Amount $\left(\mathrm{g} \mathrm{kg}^{-1}\right)$} \\
\hline & Upper & Lower & Upper & Lower & Upper & Lower & Upper & Lower & Upper & Lower \\
\hline Raw soymilk & $60.8 \pm 0.4$ & 39.2 & $4.2 \pm 0.0$ & $11.2 \pm 0.1$ & 25.5 & 43.8 & $0.5 \pm 0.0$ & $8.2 \pm 0.1$ & 3.0 & 32.2 \\
\hline 50 & $56.1 \pm 0.8$ & 43.9 & $4.1 \pm 0.1$ & $10.5 \pm 0.1$ & 23.2 & 46.2 & $0.5 \pm 0.0$ & $7.5 \pm 0.2$ & 2.7 & 32.9 \\
\hline 55 & $49.6 \pm 0.3$ & 50.4 & $4.1 \pm 0.0$ & $9.6 \pm 0.1$ & 20.4 & 48.6 & $0.5 \pm 0.0$ & $6.5 \pm 0.2$ & 2.6 & 32.8 \\
\hline 60 & $45.2 \pm 0.7$ & 54.8 & $4.1 \pm 0.0$ & $9.2 \pm 0.1$ & 18.5 & 50.2 & $0.5 \pm 0.0$ & $6.0 \pm 0.1$ & 2.3 & 33.1 \\
\hline 65 & $36.4 \pm 0.5$ & 63.6 & $4.0 \pm 0.0$ & $8.7 \pm 0.1$ & 14.6 & 55.0 & $0.4 \pm 0.0$ & $5.4 \pm 0.1$ & 1.5 & 34.1 \\
\hline 70 & $25.5 \pm 0.4$ & 74.5 & $4.2 \pm 0.1$ & $8.1 \pm 0.0$ & 10.6 & 60.1 & $0.3 \pm 0.1$ & $4.7 \pm 0.1$ & 0.8 & 34.9 \\
\hline 75 & $6.4 \pm 0.7$ & 93.6 & $4.2 \pm 0.1$ & $7.2 \pm 0.1$ & 2.7 & 67.5 & $0.2 \pm 0.0$ & $3.8 \pm 0.0$ & 0.1 & 35.8 \\
\hline 80 & 0.0 & 100.0 & _* & $7.1 \pm 0.1$ & - & 70.6 & - & $3.6 \pm 0.0$ & - & 36.0 \\
\hline
\end{tabular}

Upper, upper layer; Lower, lower layer.

${ }^{*}$ Could not separate. Values are means \pm standard deviation $(n=3)$.

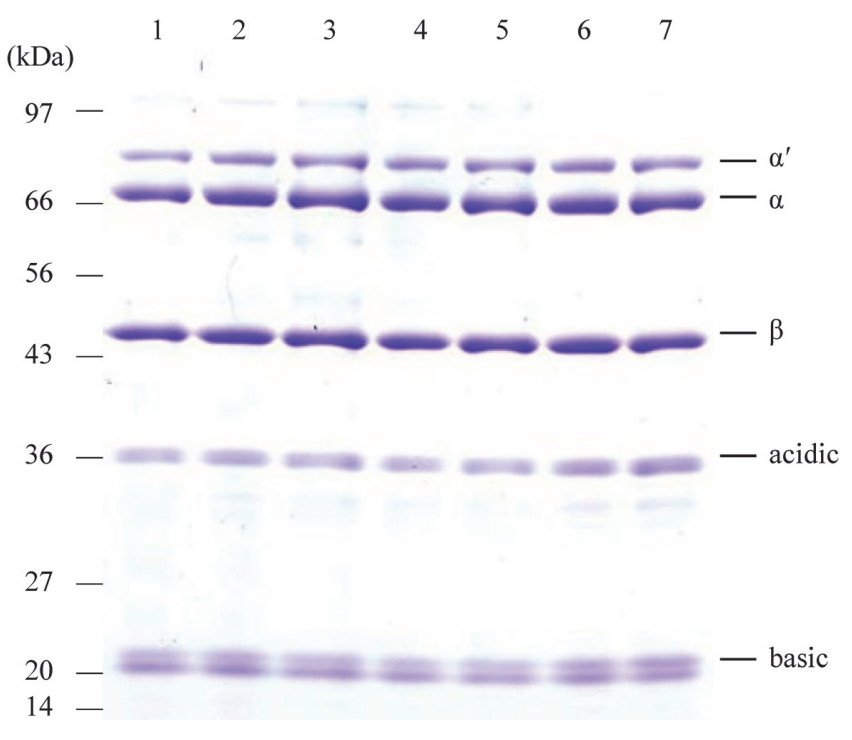

Fig. 2. SDS-PAGE patterns of the upper layers of soymilk heated to different temperatures before freezing.

1, Raw soymilk; Soymilk heated to different temperatures before freezing: $2,50^{\circ} \mathrm{C} ; 3,55^{\circ} \mathrm{C} ; 4,60^{\circ} \mathrm{C} ; 5,65^{\circ} \mathrm{C} ; 6,70^{\circ} \mathrm{C} ; 7,75^{\circ} \mathrm{C}$.

$\alpha^{\prime}, \alpha^{\prime}$-subunit of $\beta$-conglycinin; $\alpha, \alpha$-subunit of $\beta$-conglycinin; $\beta$, $\beta$-subunit of $\beta$-conglycinin; acidic, acidic polypeptides of glycinin; basic, basic polypeptides of glycinin.

proteins from the upper layer, bands corresponding to 7S $\left(\alpha^{\prime}, \alpha\right.$, and $\beta$ ) were more intense than those corresponding to $11 \mathrm{~S}$ (acidic and basic) at all tested heating temperatures (Fig. 2). The patterns were similar for all tested heating temperatures. For the lower layer, the acidic and basic polypeptide bands derived from $11 \mathrm{~S}$ were more intense than those of the subunits derived from $7 \mathrm{~S}$ at $50^{\circ} \mathrm{C}$, whereas the intensity of the bands corresponding to $11 \mathrm{~S}$ decreased as the heating temperature increased (Fig. 3). In contrast, the intensity of the bands corresponding to the $7 \mathrm{~S}$ subunit was maintained at all temperatures. The protein content of the lower layer decreased as the heating temperature increased (Table 1), even though the $7 \mathrm{~S}$ content did not decrease; therefore, we

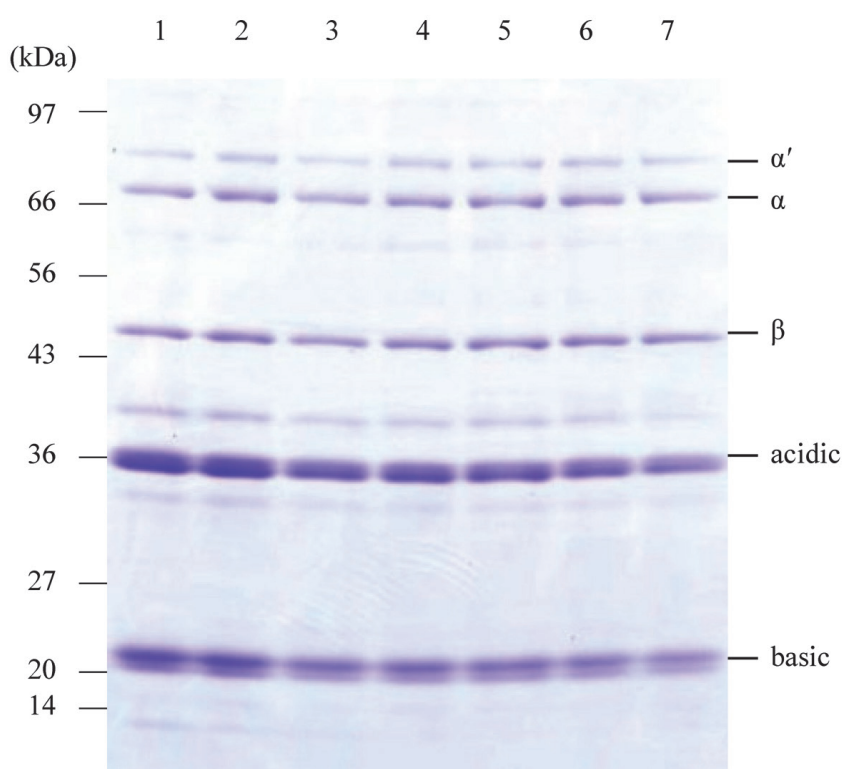

Fig. 3. SDS-PAGE patterns of the lower layers of soymilk heated to different temperatures before freezing.

1, Raw soymilk; Soymilk heated to different temperatures before freezing: $2,50^{\circ} \mathrm{C} ; 3,55^{\circ} \mathrm{C} ; 4,60^{\circ} \mathrm{C} ; 5,65^{\circ} \mathrm{C} ; 6,70^{\circ} \mathrm{C} ; 7,75^{\circ} \mathrm{C}$

$\alpha^{\prime}, \alpha^{\prime}$-subunit of $\beta$-conglycinin; $\alpha, \alpha$-subunit of $\beta$-conglycinin; $\beta$, $\beta$-subunit of $\beta$-conglycinin; acidic, acidic polypeptides of glycinin; basic, basic polypeptides of glycinin.

concluded that part of 7S, which was originally in the upper layer, was transferred into the lower layer upon heating before freezing.

In raw soymilk, some proteins interact with lipid emulsions (oil bodies) to form lipid/protein complexes (Ono et al., 1991; Guo et al., 1997). The primary protein constituent of lipid/protein complexes is $11 \mathrm{~S}$, and the intensity of the corresponding band was greater than that of 7S (Ono et al., 1991). The protein components in the lipid/protein complexes in raw soymilk are liberated upon heating at temperatures greater than $65^{\circ} \mathrm{C}$ (Ono et al., 1991; Guo et al., 1997). Moreover, a conformational change in 7S occurs between 65 and $75^{\circ} \mathrm{C}$, and $7 \mathrm{~S}$ is completely denatured at $75^{\circ} \mathrm{C}$. However, $11 \mathrm{~S}$ begins to denature at $80^{\circ} \mathrm{C}$ and is completely 


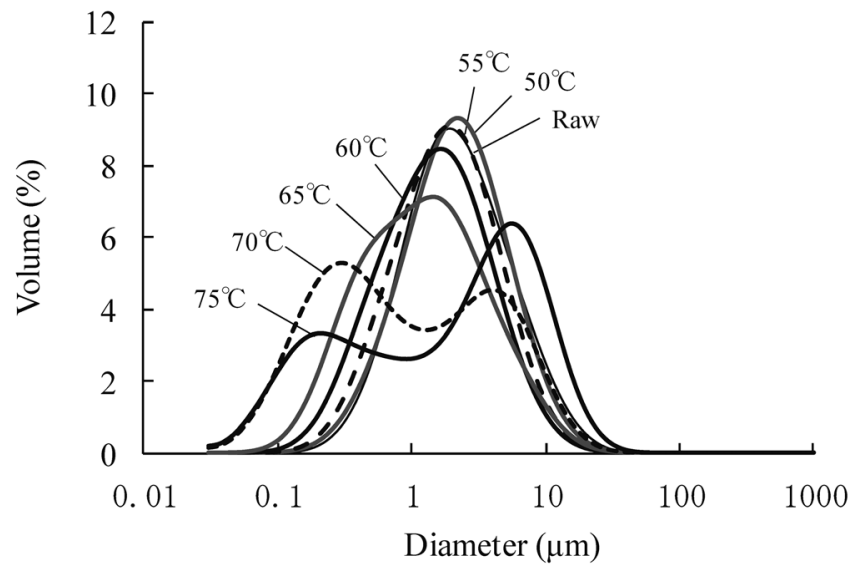

Fig. 4. Particle size distributions of the upper layers of freeze-thawed soymilk heated to different temperatures before freezing.

denatured at $91^{\circ} \mathrm{C}$ (Hermansson, 1986; Iwabuchi et al., 1991; Sorgentini et al., 1995; Nagano et al., 1995). In addition, soymilk proteins aggregate upon heating (Guo et al., 1997). Accordingly, $7 \mathrm{~S}$ forms soluble aggregates in raw soymilk upon freeze-mediated concentration (Morita and Shimoyamada, 2013), whereas 7S may form insoluble aggregates upon denaturation due to heating. Thus, the thermally denatured part of $7 \mathrm{~S}$ and the lipid/protein complexes were considered to be interacted and aggregated upon freezemediated concentration, causing part of $7 \mathrm{~S}$ to migrate to the lower layer.

Particle size distribution of soymilk Next, to verify whether the proteins and lipids (oil bodies) form complexes in soymilk, we measured the particle size distribution. The particle size distribution in the upper layer of freeze-thawed soymilk heated to various temperatures prior to freezing was estimated using a laser diffraction particle size analyzer (Fig. 4). The particle size of the upper layer decreased as the heating temperature increased, and heating at 70 and $75^{\circ} \mathrm{C}$ lead to bimodal distributions. The peak at around $0.3 \mu \mathrm{m}$ may represent particles comprised of a single oil body (Tzen et al., 1990; Huang, 1992). The oil bodies were dissociated upon heating at 70 and $75^{\circ} \mathrm{C}$, and $7 \mathrm{~S}$ could be liberated from the lipid/protein complexes. Particles ranging from 1 to $20 \mu \mathrm{m}$ in diameter corresponded to partially denatured $7 \mathrm{~S}$ globulins, which were liberated from the lipid/protein complexes, selfaggregated, and interacted with lipid/protein complexes upon freeze-mediated concentration to afford slightly larger particles.

On the other hand, the particle size of the lower layer increased as the heating temperature increased (Fig. 5). Notably, with heating temperatures greater than $70^{\circ} \mathrm{C}$, the ratio of the particles over $10 \mu \mathrm{m}$ in diameter increased. This may have played a role in the volume of the lower layer sharply increasing when compared with the upper layer above $70^{\circ} \mathrm{C}$ (Fig. 1), and the changes in particle size distribution of the upper layer (Fig. 4). Upon heating to temperatures greater than $85^{\circ} \mathrm{C}, 11 \mathrm{~S}$ as well as $7 \mathrm{~S}$ are liberated from oil bodies and are denatured, and the denatured $7 \mathrm{~S}$ and $11 \mathrm{~S}$

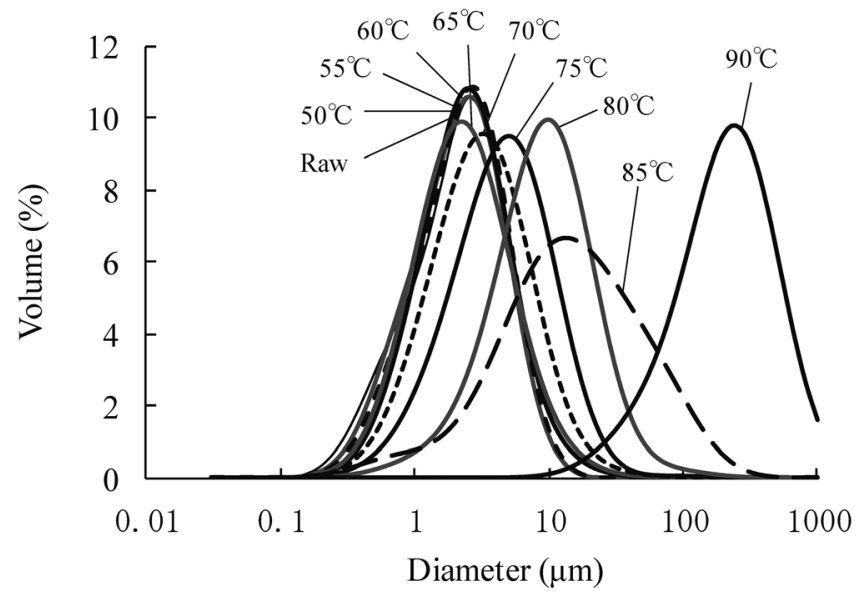

Fig. 5. Particle size distributions of the lower layers of freeze-thawed soymilk heated to different temperatures before freezing.

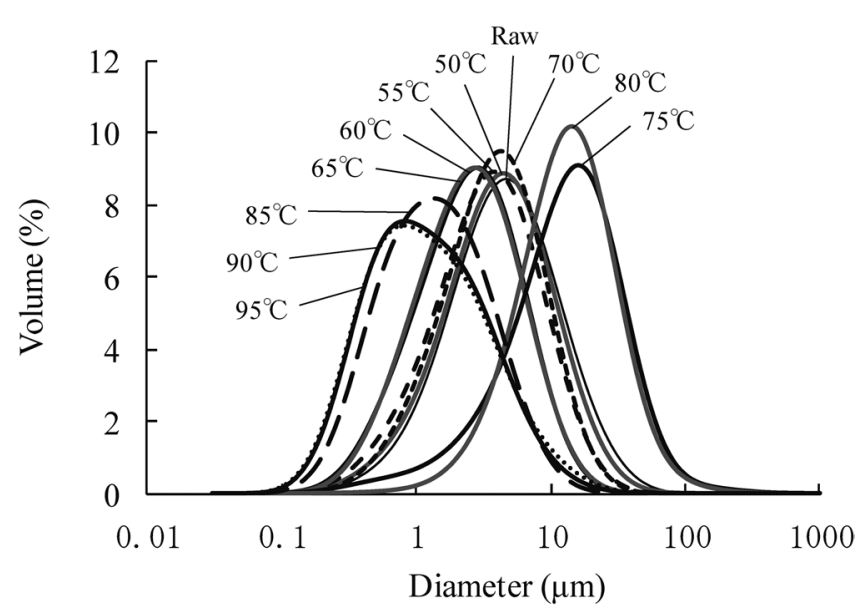

Fig. 6. Particle size distributions of the soymilk heated to various temperatures without freeze-thawing.

globulins aggregate (Guo et al., 1997). In heated soymilk, the denatured protein particles were transformed into larger insoluble aggregates by freeze-mediated concentration.

In addition, to verify whether the changes in particle size distribution depend on freeze-thawing, the particle size distribution of unfrozen soymilk was measured immediately after heating $\left(50-95^{\circ} \mathrm{C}\right)$ (Fig. 6). The particle size distributions of soymilk decreased slightly from 60 to $65^{\circ} \mathrm{C}$, increased from 70 to $80^{\circ} \mathrm{C}$, and decreased again at temperatures above $85^{\circ} \mathrm{C}$. Upon heating to $70-80^{\circ} \mathrm{C}$, only $7 \mathrm{~S}$ is denatured and liberated from lipid/protein complexes. Some liberated $7 \mathrm{~S}$ and lipid/protein complexes are likely to again interact to afford larger lipid/protein complexes (around $10 \mu \mathrm{m}$ ). Therefore, it is assumed that the smaller particles move into the upper layer, whereas the larger particles move into the lower layer during freeze-thawing. Moreover, when heated above $85^{\circ} \mathrm{C}, 11 \mathrm{~S}$ is liberated from lipid/protein complexes, resulting in the dispersion of $7 \mathrm{~S}$ and $11 \mathrm{~S}$ and individual oil bodies with few bound proteins (Ono, 2008). Thus, the particle size distribution decreased. Proteins in the dispersion form insoluble 


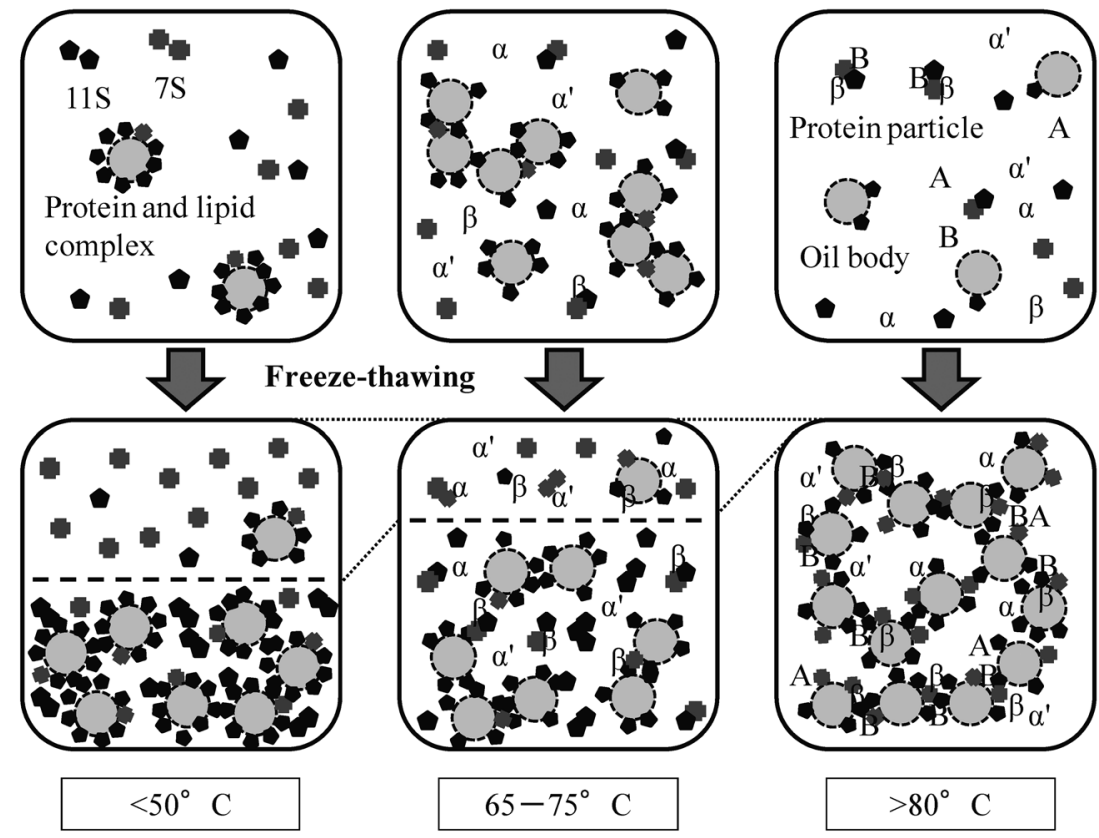

Fig. 7. Proposed mechanism of soymilk fractionation by freeze-thawing after heating to different temperatures.

$\alpha^{\prime}, \alpha^{\prime}$-subunit of $\beta$-conglycinin; $\alpha, \alpha$-subunit of $\beta$-conglycinin; $\beta, \beta$-subunit of $\beta$-conglycinin; $\mathrm{A}$, acidic polypeptides of glycinin; $\mathrm{B}$, basic polypeptides of glycinin.

aggregates by freeze-mediated concentration. Notably, Shimoyamada et al. (2000) also reported that the coagulation of heated soymilk by the freeze-thaw process was due to the increase in disulfide and/or hydrophobic interactions among proteins that were concentrated during freezing.

Proposed mechanism for changes in properties of soymilk heated at various temperatures Considering these results, we propose a mechanism by which heating before freeze-thawing results in changes in the properties of soymilk, as schematically represented in Fig. 7.

In raw soymilk $\left(<50^{\circ} \mathrm{C}\right), 7 \mathrm{~S}$ and $11 \mathrm{~S}$ proteins, and protein/lipid complexes are present. Upon freezing, the proteins, primarily $11 \mathrm{~S}$, and protein/lipid complexes are concentrated in the unfrozen parts, surrounded by ice crystals, and form insoluble aggregates. The aggregates precipitate after thawing. The $7 \mathrm{~S}$ globulin, which may form soluble aggregates due to its high hydrophilicity, is retained in the supernatant (Morita and Shimoyamada, 2013).

Upon heating to $65-75^{\circ} \mathrm{C}, 7 \mathrm{~S}$ is liberated from the lipid/ protein complexes and is denatured; the denatured $7 \mathrm{~S}$ interacts with lipid/protein complexes, which are primarily comprised of the $11 \mathrm{~S}$ globulin/oil body complexes. Upon freezing, the proteins and complexes aggregate due to freeze-mediated concentration, resulting in a decrease in the volume of the upper layer after thawing.

Upon heating to temperatures greater than $80^{\circ} \mathrm{C}, 11 \mathrm{~S}$ as well as $7 \mathrm{~S}$ are liberated from the lipid/protein complexes, and the protein particles comprised of $7 \mathrm{~S}$ and $11 \mathrm{~S}$ and almost bare oil bodies are dispersed in the soymilk (Guo et al., 1997; Ono, 2008). Due to the high reactivity of the denatured and aggregated protein particles, the protein particles and oil bodies form large insoluble coagulants by freeze-mediated concentration.

Previous studies reported the freeze denaturation of heated soy proteins, where proteins were denatured by heating (Hashizume, 1971; Shimoyamada et al., 1999). However, in this study, we investigated the freeze denaturation of soy proteins partially denatured by heating at various temperatures, and demonstrated that the freeze denaturation of partially denatured proteins was different from that of denatured proteins. Thus, partially denatured soy proteins may have implications in food processing, and might be useful for the development of novel foods comprised of soy proteins. Moreover, considering the application of the freezethawed soymilk, especially pre-heated at lower temperature before freezing, further sufficient heating process must be again required in food processing, because of sterilization and inactivation of trypsin inhibitor and hemagglutinin in soymilk. Thus, the effect of second heating on the properties of freeze-thawed soymilk should be studied in future.

\section{References}

Bligh, E. G. and Dyer, W. J. (1959). A rapid method of total lipid extraction and purification. Can. J. Biochem. Physiol., 37, 911-917.

Guo, S. T., Ono, T., and Mikami, M. (1997). Interaction between protein and lipid in soybean milk at elevated temperature. J. Agric. Food Chem., 45, 4601-4605.

Hashizume, K., Kakiuchi, K., Koyama, E., and Watanabe, T. (1971) Denaturation of soybean protein by freezing Part I. Agric. Biol. Chem., 35, 449-459.

Hashizume, K. (1979). Studies on production of new textured protein by 
freeze denaturation of soybean protein. Nippon Shokuhin Kogyo Gakkaishi, 26, 450-459 (in Japanese).

Hermansson, A. M. (1986). Soy protein gelation. J. Am. Oil Chem. Soc., 63, 658-666.

Huang, A. H. C. (1992). Oil bodies and oleosins in seeds. Annu. Rev. Plant Physiol. Plant Mol. Biol., 43, 177-200.

Iwabuchi, S., Watanabe, H., and Yamauchi, F. (1991). Thermal denaturation of $\beta$-conglycinin. Kinetic resolution of reaction mechanism. J. Agric. Food Chem., 39, 27-33.

Kjeldahl, J. (1883). Neue methode zur bestimmung des stickstoffs in organischen körpern. Z. Anal. Chem., 22, 366-382.

Leammli, U. K. (1970). Cleavage of structural proteins during the assembly of the head of bacteriophage T4. Nature, 227, 680-685.

Morita, K. and Yokoi, K. (2011). Simple freeze-thaw fractionation of 7S and $11 \mathrm{~S}$ globulins in soymilk. J. Jpn. Soc. Food Sci. Technol. (Nippon Shokuhin Kagaku Kogaku Kaishi), 58, 392-397 (in Japanese).

Morita, K. (2013). Simple freeze-thaw fractionation of proteins in soymilk. J. Jpn. Soc. Food Sci. Technol. (Nippon Shokuhin Kagaku Kogaku Kaishi), 60, 199-203 (in Japanese).

Morita, K. and Shimoyamada, M. (2013). Proposal of mechanism of the freeze-thaw fractionation of $7 \mathrm{~S}$ and $11 \mathrm{~S}$ globulins in soymilk. Food Chem., 140, 39-43.

Nagano, T., Akasaka, T., and Nishinari, K. (1995). Study on the heatinduced conformational changes of $\beta$-conglycinin by FTIR and CD analysis. Food Hydrocolloids, 9, 83-89.

Ono, T., Choi, M. R., Ikeda, A., and Odagiri, S. (1991). Changes in the composition and size distribution of soymilk protein particles by heating. Agric. Biol. Chem., 55, 2291-2297.

Ono, T. (2008). The mechanism of soymilk and tofu formation from soybean, and the factors affecting the formation. J. Jpn. Soc. Food Sci. Technol. (Nippon Shokuhin Kagaku Kogaku Kaishi), 55, 39-48 (in Japanese).

Shimoyamada, M., Tomatsu, K., and Watanabe, K. (1999). Insolubilisation and gelation of heat-frozen soymilk. J. Sci. Food Agric., 79, 253-256.

Shimoyamada, M., Tomatsu, K., Oku, S., and Watanabe, K. (2000). Interactions among protein molecules in freeze-gel of soymilk and protein structures in heated soymilk during cooling. J. Agric. Food Chem., 48, 2775-2779.

Sorgentini, D. A., Wagner, J. R., and Anon, M. C. (1995). Effects of thermal treatment of soy protein isolate on the characteristics and structure-function relationship of soluble and insoluble fractions. $J$. Agric. Food Chem., 43, 2471-2479.

Toda, K., Chiba, K., and Ono, T. (2007). Effect of components extracted from okara on the physicochemical properties of soymilk and tofu texture. J. Food Sci., 72, C108-C113.

Tzen, J. T. C., Lai, Y. K., Chan, K. L., and Huang, A. H. C. (1990). Oleosin isoforms of high and low molecular weights are present in the oil bodies of diverse seed species. Plant Physiol., 94, 1282-1289. 